\title{
DETERMINASI TRANSFER PRICING PADA PERUSAHAAN MANUFAKTUR DI INDONESIA
}

\author{
Dinda Oktaviyanti, Ni Putu Eka Widiastuti, Satria Yudhia Wijaya \\ Program Studi Akuntansi Universitas Pembangunan Nasional Veteran Jakarta, Indonesia \\ dinda.oktaviyanti@upnvj.ac.id, putueka@upnvj.ac.id, satria.wijaya@upnvj.ac.id
}

\begin{abstract}
This study aims to determine the effect of income tax, tunneling incentive, and debt covenant on transfer pricing indications. The research population uses manufacturing companies listed on the Indonesia Stock Exchange (IDX) in 20152019. The sampling technique was carried out by purposive sampling method. The study used 105 observational data. Logistic regression is a data analysis technique used in this study. The results of the study show that there is an effect of tunneling incentive, which is measured by the amount of foreign share ownership that exceeds $20 \%$ on transfer pricing. However, this study cannot prove the effect of income tax, as measured by the different box tax and debt covenants, as measured by the debt to equity ratio on transfer pricing.
\end{abstract}

Keywords: transfer pricing, income tax, tunneling incentive, debt covenant

\begin{abstract}
ABSTRAK
Penelitian ini bertujuan untuk mengetahui pengaruh pajak penghasilan, tunneling incentive, dan debt covenant terhadap indikasi transfer pricing. Populasi penelitian menggunakan perusahaan manufaktur yang terdaftar di Bursa Efek Indonesia (BEI) tahun 2015-2019. Teknik pengambilan sampel dilakukan dengan metode purposive sampling. Penelitian menggunakan 105 data observasi. Regresi logistik merupakan teknik analisis data yang digunakan dalam penelitian ini. Hasil dari penelitian menunjukkan terdapat pengaruh tunneling incentive, yang diukur berdasarkan besarnya kepemilikan saham asing yang melebihi $20 \%$ terhadap transfer pricing. Namun penelitian ini tidak dapat membuktikan pengaruh pajak penghasilan, yang diukur dengan boox tax different dan debt covenant, yang diukur dengan debt to equity ratio terhadap transfer pricing.
\end{abstract}

Kata kunci: transfer pricing, pajak penghasilan, tunneling incentive, debt covenant

\section{PENDAHULUAN}

Transfer pricing yakni suatu transaksi sejumlah transfer atas barang serta jasa yang dilakukan oleh perusahaan. Proses transaksi ini terbagi dalam dua kelompok yakni intracompany serta intercompany transfer pricing. Transaksi harga terjadi antar pengiriman pada tiap divisi yang ada pada suatu perusahaan disebut intracompany transfer pricing. Transaksi harga transfer yang terjadi pada dua perusahaan yang mempunyai relasi istimewa disebut intercompany transfer pricing. Transaksi tersebut akan terjadi apabila kedua perusahaan bertempat di 
negara yang sama atau merupakan anak perusahaan dari negara maju (Andayani dan Sulistyawati, 2020; Putri, 2018).

Praktik transfer pricing yang dijalankan perusahaan multinasional merupakan bentuk penghindaran pajak (tax avoidance). Ketika suatu grup usaha yang beroperasi disuatu negara atau lebih dan melakukan transaksi afiliasi yang merugikan penerimaan negara, maka hal tersebut dapat dikatakan sebagai transfer pricing. Peristiwa tersebut timbul disebabkan oleh perusahaan multinasional yang memindahkan hasil pendapatan yang berasal dari negara yang pajaknya lebih tinggi dari negara lainnya (Amanah dan Suyono, 2020; Osho dan Ilori, 2020).

Aturan yang berlaku terkait transfer pricing tertera pada Pasal 18 UndangUndang Nomor 36 Tahun 2008 tentang Pajak Penghasilan. Pasal ini menetapkan bahwa Direktur Jenderal Pajak berhak merumuskan kembali aturan mengenai penghasilan dan pemotongan berdasarkan kewajaran dan praktek bisnis yang tidak terpengaruh oleh hubungan istimewa, dan menetapkan hutang yang digunakan sebagai modal hitungan hubungan istimewa Wajib Pajak dengan Wajib Pajak lainnya.

Perusahaan otomotif terbesar PT Toyota Motor Manufacturing Indonesia (TMMIN) telah menerapkan praktik transfer pricing. Kasus tersebut bermula ketika PT Toyota mengajukan permohonan restitusi pajak sebesar 412 miliar pada tahun 2005, 2007, dan 2008. DJP melakukan pemeriksaan atas permintaan tersebut. Pada tahun 2003 terjadi restrukturisasi, di mana pemegang saham PT Toyota adalah Toyota Motor Corporation Jepang yang memegang 95\% sahamnya dan 5\% sisanya dimiliki oleh PT Astra International Tbk. Sebelum tahun 2003, departemen perakitan mobil TMMIN masih bergabung dengan PT Toyota Astra Motor (TAM), namun setelah tahun 2003 perakitan mobil dipisahkan. Setelah dilakukan restrukturisasi pada tahun 2004, laba gabungan dari kedua perusahaan anjlok, dan pajak yang terutang kepada pemerintah menurun, dan omset produksi dan penjualan meningkat sebesar $40 \%$. Hal ini ditunjukkan dengan laba bruto yang turun awalnya yakni Rp 1,5 triliun akhirnya Rp 950 miliar dengan persentase lebih dari 30\%, dan terjadi penurunan rasio gross margin dari $14,59 \%$ menjadi $6,58 \%$. Sebelum pemisahan, rasio gross margin TAM meningkat sebesar 11\% sampai 14\%/tahun. Setelah pemisahan rasio gross margin TMMIN sekitar 1,8\% sampai dengan 3\%/tahun, sementara TAM sekitar 3,8\% sampai 5\% per tahun. Artinya, apabila rasio gross margin TMMIN dan TAM digabungkan, hanya diperoleh persentase sebanyak 7\% yang lebih sedikit, jika dibandingkan saat kedua perusahaan tersebut digabung yang mencapai $14 \%$. Penurunan rasio gross margin tersebut disebabkan karena adanya indikasi transfer pricing dengan harga yang di luar prinsip kewajaran usaha. Hal ini terjadi karena TMMIN mengalihkan pendapatan yang diperolehnya dari Indonesia ke Singapura yaitu pada Toyota Motor Asia Pacific Pte., Ltd, dan memasarkan ke Toyota Astra Motor dengan harga yang ditawarkan lebih kecil dari harga pasar. 
Merujuk pada pedoman transfer pricing yang disusun oleh OECD, DJP menggunakan cara Comparable Uncontrolled Price (CUP) yang membuat perbandingan harga melalui transaksi perusahaan serupa di negara lain. Melalui metode CUP ini, DJP melakukan perbandingan pada 5 perusahaan otomotif yang mempunyai karakteristik yang sama yaitu Yulon Motor (Taiwan), Hindustan Motors (India), Dongan Heibao (China), Shenyang Jinbei, dan Force Motor Limited (India). DJP menemukan bahwa rasio gross margin berada di bawah nilai wajar, sehingga DJP menyimpulkan bahwa terjadi praktik transfer pricing untuk penghindaran pajak. Selain melakukan transaksi penjualan dengan pihak afiliasi diluar prinsip kewajaran dan kelaziman usaha, TMMIN juga meningkatkan beban biaya melalui pembayaran royalti yang tidak sewajarnya, terutama kepada perusahaan induk Toyota yang berada di Jepang.

Terdapat beberapa faktor yang membuat perusahaan multinasional mengambil tindakan transfer pricing. Seperti yang dikemukakan oleh penelitian Ayu, dkk (2017), bahwasannya pajak memberikan pengaruh terhadap indikator transfer pricing. Proses ini melibatkan perusahaan afiliasi, berlokasi pada negara atau wilayah yang berbeda. Dengan tujuan agar mengurangi total pajak yang harus perusahaan bayar tersebut. Penelitian ini juga didukung oleh Wijaya dan Amalia (2020) yang menyebutkan bahwasannya pajak berpengaruh positif pada transfer pricing. Hasilnya menyimpulkan bahwa semakin tinggi motivasi perusahaan dalam mengambil keputusan kegiatan transfer pricing yang dipengaruhi oleh jumlah pajak yang semakin besar. Berbeda dengan penelitian sebelumnya, Andayani dan Sulistyawati (2020) dan Tjandrakirana dan Diani (2020) berpendapat pajak tidak mempengaruhi keputusan perusahaan menerapkan transfer pricing. Perusahaan yang pajaknya kecil, memiliki kemungkinan untuk tidak melakukan manipulasi pajak melalui transfer pricing.

Penyebab lainnya yang mungkin memberikan pengaruh pada perusahaan memutuskan untuk transfer pricing ialah dengan tunneling incentive. Tunneling dapat didefinisikan sebagai kegiatan pemindahan harta benda perusahaan. Praktik tunneling termasuk transaksi antara company with owner melalui aset yang dijual, peminjaman, pemberian ganti rugi eksekutif terlalu besar, penerbitan saham dilutif, kontrak harga pengalihan, atau transaksi lainnya yang memungkinkan untuk memberatkan pemegang saham bukan pengendali. Jika semakin banyak aktivitas tunneling yang dilakukan, maka aktivitas transfer picing juga akan semakin meningkat (Suryarini dkk, 2020).

Penelitian terkait pengaruh tunneling incentive terhadap ketetapan transfer pricing, diantaranya Andayani dan Sulistyawati (2020) serta Ayu et al. (2017) mengemukakan tunneling incentive memiliki pengaruh positif terhadap ketetapan perusahaan melakukan transfer pricing. Kepemilikan perusahaan dikendalikan oleh beberapa pihak yang mengontrol perusahaan tersebut, dan seringkali akan mengambil tindakan yang hanya bermanfaat bagi dirinya sendiri. Hal tersebut bisa 
dicapai melalui tunneling yakni melakukan transaksi transfer pricing guna menambahkan pengembalian atau dividen yang akan diperoleh pemilik saham pengendali, namun pemilik saham non pengendali hanya turut memikul beban dari transaksi tersebut. Hasil tersebut tidak sejalan dengan Nabila dkk (2020) yang mengatakan bahwa tunneling incentive tidak berpengaruh terhadap transfer pricing, serta didukung oleh Wijaya dan Amalia (2020) menyatakan bahwa perusahaan asing yang mempunyai modal saham lebih dari $20 \%$ tidak akan menempatkan pemilik saham asing pada kedudukan yang menguntungkan untuk mengendalikan ketetapan transfer pricing.

Hal lainnya yang mungkin memberikan pengaruh pada perusahaan memutuskan untuk transfer pricing adalah debt covenant. Debt covenant menggunakan rasio leverage sebagai proksi, dimana leverage ialah rasio pembanding antara total utang dengan total aset yang dipunyai oleh perusahaan. Perbandingan tersebut digunakan sebagai tolok ukur atas kemungkinan untuk dapat membayar tagihan suatu utang, sehingga dapat menyampaikan representasi mengenai struktur modal yang dimiliki perusahaan. Menurut Junaidi dan Yuniarti (2020) apabila perusahaan memiliki rasio terhadap utang yang lebih besar, maka manajer perusahaan akan dapat menggunakan cara yang dapat memberikan peningkatan pada keuntungan yang diperoleh perusahaan melalui metode akuntansi. Tjandrakirana dan Diani (2020) menjelaskan bahwa debt covenant memberikan pengaruh negatif secara signifikan terhadap ketetapan perusahaan menerapkan transfer pricing. Sedangkan Indrasti (2016) berpendapat debt covenant tidak berpengaruh terhadap transfer pricing.

Perbedaan yang terdapat dalam penelitian ini yaitu variabel independen, penulis mengikuti rekomendasi peneliti sebelumnya dengan memasukkan debt covenant sebagai variabel independen. Alasan pemilihan perusahaan manufaktur karena perusahaan multinasional cenderung menjalankan usahanya di sektor manufaktur, sehingga praktik transfer pricing akan dilakukan. Berdasarkan fenomena yang ada serta gap research yang ada belum menunjukkan bukti yang kuat dan akurat antara variabel dependen dengan independen, peneliti berminat untuk meneliti lebih mendalam mengenai "apakah pajak penghasilan, tunneling incentive, dan debt covenant berpengaruh terhadap indikasi transfer pricing?".

\section{TINJAUAN PUSTAKA DAN PENGEMBANGAN HIPOTESIS Teori Keagenan}

Jensen dan Meckling mempresentasikan teori keagenan (agency theory) pada tahun 1976. Teori ini mengartikan hubungan keagenan sebagai kontrak di mana satu atau lebih orang (prinsipal) mengimplikasikan orang lain (agen) untuk melakukan layanan tertentu atas nama mereka, yang melibatkan pelimpahan wewenang pengambilan keputusan tertentu kepada agen. Teori ini juga menjelaskan masalah insentif perusahaan (masalah prinsipal dan agen) yang 
disebabkan oleh pemecahan kepemilikan dan pengendalian sumber daya. Hal ini telah digunakan untuk menjelaskan pilihan akuntansi secara teoritis, pengungkapan sukarela, penunjukkan auditor secara sukarela, dan corporate lobbying tentang standar akuntansi yang diusulkan (Morris, 1987).

Masalah keagenan menstimulasi agen agar mengerjakan tindakan yang tidak sesuai, misalnya transfer pricing. Teori tersebut menjelaskan bahwa transfer pricing dipengaruhi oleh kepemilikan mayoritas, yang akan menciptakan potensi pertikaian kepentingan yang terjadi diantara pemegang saham baik mayoritas maupun minoritas. Bentuk pertikaian ini meliputi konflik pengambilan keputusan, transaksi antar pihak yang berhubungan istimewa, serta perbedaan pola pikir manajerial yang dapat dilihat dalam kerangka masalah keagenan.

\section{Transfer Pricing}

Menurut Organizational for Economic Co-operation and Develompment (OECD) transfer pricing merupakan harga yang ditentukan dalam transaksi antar anggota grup perusahaan multinasional, di mana harga pengalihan yang ditentukan dapat menyimpang dari harga pasar yang wajar, selama sesuai untuk grup tersebut. Karena posisi para pihak yang pada situasi tidak terikat, dapat mengambil prinsip manapun yang memiliki kesesuaian untuk perusahannya, dan pihak ini dapat memilih pilihan yang tidak sesuai dengan standart market price.

Pada dasarnya praktik transfer pricing bisa dilakukan sebab adanya hubungan khusus (hubungan istimewa) antar perusahaan multinasional, hal ini mengakibatkan adanya negosiasi dan kerja sama untuk menentukan harga transfer (Tarigan, 2017). Hal inilah yang menyebabkan transfer pricing dianggap negatif, karena ketika transaksi terjadi antar pihak dengan hubungan khusus tersebut dibuktikan dapat merugikan penerimaan negara.

\section{Pajak Penghasilan}

Menurut UU Nomor 36 Tahun 2008 tentang Pajak Penghasilan, pajak penghasilan adalah pajak yang dikenakan terhadap subjek pajak atas penghasilan yang diterima atau diperolehnya dalam 1 tahun pajak. Peraturan perpajakan terkait transfer pricing merupakan aturan yang dikenakan pada usaha bisnis yang sesuai dengan standar dan tanpa pengaruh hubungan khusus. Wajib pajak maupun badan usaha yang terafiliasi melakukan pembayaran pajak berdasarkan penggunaannya untuk bertransaksi, serta mencatat pelaksanaan standar atas kewajaran dan kelaziman usaha saat menentukan harga transaksi, dan diharuskan melampirkan dokumen sesuai keperluan yang digunakan untuk memastikan transfer pricing dilakukan berdasarkan atas arm's length principle (Sari dan Puryandani, 2019). 


\section{Tunneling Incentive}

Tunneling incentive ialah perilaku dimana pemilik saham uang mayoritas (dominan) mengalihkan aset (barang berharga) serta keuntungan perusahaan untuk keperluan pribadi. Oleh karena itu, walaupun pengalihan tersebut hanya menguntungkan pemilik saham mayoritas, serta pemilik saham minoritas harus membayar akan biaya yang dibebankan (Hartati dkk, 2015).

Terdapat dua bentuk munculnya tunneling incentive. Pertama, pemilik saham pengendali akan dapat mengalihkan aset yang dimiliki oleh perusahaan untuk kepentingan mereka sendiri. Transaksi semacam itu termasuk pencurian atau penipuan langsung yang ilegal di mana-mana (meski sering tidak terdeteksi atau tidak dihukum), tetapi transaksi tersebut juga memperdagangkan kepemilikan dan perjanjian contohnya transfer pricing yang memberikan laba bagi pemilik saham pengendali, pemberian pinjaman, ganti rugi eksekutif yang terlalu besar, pengambilalihan peluang perusahaan, serta yang lain. Kedua, pemilik saham pengendali diharapkan menambahkan sahamnya di perusahaan dengan menerbitkan saham dilutif, membekukan saham pemegang saham minoritas yang akan dapat mendiskriminasi pemegang saham minoritas tanpa mengalihkan aset (Johnson dkk, 2000).

\section{Debt Covenant}

Debt covenant adalah perjanjian antara pemberi pinjaman (kreditor) dan peminjam (debitor) yang memberikan batasan rasio finansial yang tidak boleh dilanggar oleh peminjam (Tjandrakirana dan Diani, 2020). Perjanjian ini membatasi kemampuan manajer untuk berinvestasi, mengambil utang tambahan, dan membayar dividen serta membatasi tindakan yang berpotensi merugikan pemegang obligasi.

Perjanjian utang merupakan suatu kondisi yang mewajibkan untuk terpenuhinya oleh perusahaan yang diharapkan dapat menjaga rasio umum terkait dengan data akuntansi, seperti perbandingan utang terhadap keseluruhan modal. Bertambahnya utang yang dimiliki perusahaan sejalan dengan semakin ketat persyaratan yang diajukan oleh pihak pemberi utang, dan adanya kemungkinan memilih metode akuntansi untuk dapat meningkatkan laba yang besar akan dilakukan manajer. Salah satu cara yang dapat dikerjakan untuk menambah keuntungan serta menghindari aturan kredit ialah melalui transfer pricing (Indrasti, 2016; Junaidi dan Yuniarti, 2020). Debt covenant dapat mempengaruhi transfer pricing karena dapat diartikan memiliki pengendalian manajemen yang dianggap memiliki hubungan istimewa dalam perjanjian utang.

Dari uraian latar dan kajian teori, maka kerangka penelitian ini sebagai berikut: 


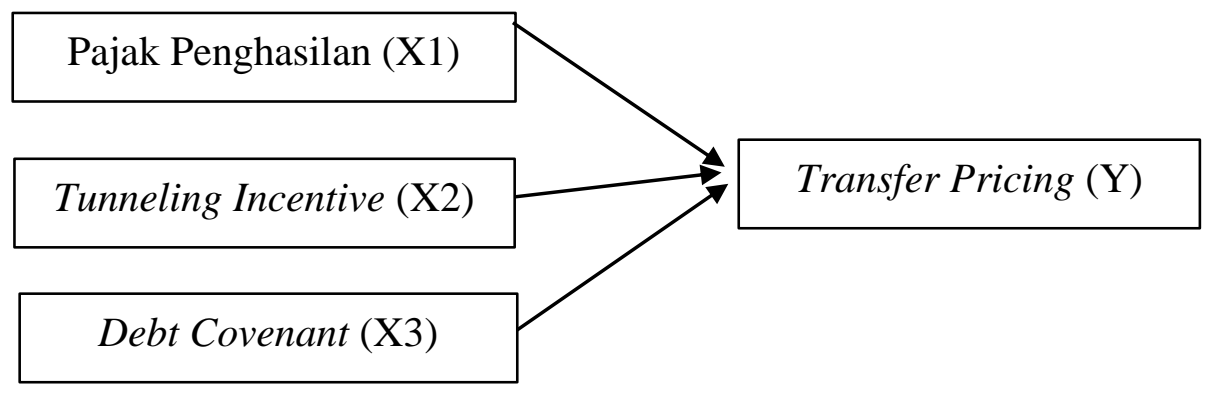

Gambar 1. Model Penelitian

\section{Pengaruh Pajak Penghasilan Terhadap Transfer Pricing}

Umumnya perusahaan menjauhi pembayaran pajak yang besar. Perusahaan akan mengungkapkan laba yang lebih kecil dalam laporan keuangannya. Salah satu upaya bagi perusahaan untuk mengurangi keuntungan adalah melalui transfer pricing. Perusahaan multinasional sepatutnya mengaplikasikan prinsip harga yang wajar digunakan untuk mengecilkan kewajiban pajak, tetapi kebanyakan transfer pricing digunakan oleh perusahaan, sehingga pertikaian keagenan dapat terjadi antara prinsipal dan agen. Sejalan dengan penelitian Jumaidi dkk (2018) serta Wijaya dan Amalia (2020) menunjukkan bahwa pajak memiliki pengaruh positif yang signifikan terhadap ketetapan perusahaan untuk melaksanakan transfer pricing. Sesuai dengan uraian di atas maka dapat disusun hipotesis:

H1: Pajak Penghasilan berpengaruh positif terhadap indikasi transfer pricing

\section{Pengaruh Tunneling Incentive Terhadap Transfer Pricing}

Ayu, dkk (2017) menerangkan bahwa tunneling incentive berpengaruh positif pada keputusan perusahaan untuk menerapkan transfer pricing, dimana perusahaan dengan kepemilikan yang hanya dikendalikan oleh beberapa pihak dan pihak yang mengendalikan perusahaan tersebut sering melakukan tindakan yang hanya bermanfaat bagi dirinya sendiri. Dengan menggunakan tunneling akan dapat tercapai hal tersebut dengan melaksanakan transaksi transfer pricing guna menambah keuntungan tersendiri bagi pemilik saham pengendali, namun non pengendali ikut serta menanggung beban dari resiko transaksi tersebut. Sesuai dengan uraian di atas maka dapat disusun hipotesis:

$\mathbf{H}_{2}$ : Tunneling Incentive berpengaruh positif terhadap indikasi transfer pricing

\section{Pengaruh Debt Covenant Terhadap Transfer Pricing}

Rasio antara utang atau ekuitas yang dimiliki oleh perusahaan, sebanding dengan kemungkinan manajer dalam pemilihan metode akuntansi yang bisa membesarkan keuntungan dan menghindari perjanjian kredit. Hal tersebut didukung oleh penelitian Junaidi dan Yuniarti, (2020) yang menyebutkan bahwa debt covenant berpengaruh positif terhadap keputusan perusahaan melakukan 
transfer pricing. Apabila debt to equity ratio (DER) suatu perusahaan menunjukkan nilai yang besar, maka hal itu akan membuat perusahaan akan melakukan transfer pricing (Tjandrakirana dan Diani, 2020). Cara yang dapat ditempuh manajemen perusahaan untuk meningkatkan keuntungan dan memungkiri aturan kredit ialah melalui transfer pricing (Indrasti, 2016). Sesuai dengan uraian di atas maka dapat disusun hipotesis:

H3: Debt Covenant berpengaruh positif terhadap indikasi transfer pricing

\section{METODE PENELITIAN}

\section{Definisi Operasional dan Pengukuran Variabel}

\section{Transfer Pricing}

Transfer pricing ialah harga barang, jasa, aset tak berwujud yang dibebankan perusahaan kepada perusahaan yang mempunyai hubungan istimewa (Lingga, 2015). Penelitian ini menggunakan variabel dummy dengan pendekatan dikotomi untuk mengukur transfer pricing yaitu dengan melihat transaksi penjualan kepada pihak berelasi. Penjualan kepada pihak berelasi ini diindikasikan sebagai praktik transfer pricing. Nilai 1 dalam variabel ini digunakan untuk menggambarkan perusahaan yang melakukan penjualan produk kepada pihak berelasi. Adapun angka 0 untuk menggambarkan perusahaan yang tidak melakukan penjualan produk kepada pihak berelasi (Mulyani dkk, 2020).

\section{Pajak Penghasilan}

Menurut Undang-Undang No 36 Tahun 2008 tentang Pajak Penghasilan. Pajak Penghasilan (PPh) adalah suatu pajak yang dikenakan terhadap orang pribadi ataupun badan berdasarkan jumlah penghasilan yang diperoleh selama satu tahun. Variabel pajak penghasilan diukur dengan menggunakan book tax different (BTD) yang mampu mempresentasikan adanya kecenderungan perencanaan pajak yang dilakukan perusahaan. Berdasarkan UU No 36 Tahun 2008 terkait Pajak Penghasilan, tarif $\mathrm{PPh}$ badan di Indonesia berkisar $25 \%$ dengan indikasi penghindaran pajak apabila perusahaan membayar pajak dengan tarif $<20 \%$. BTD digunakan untuk mengetahui seberapa besar perbedaan laba akuntansi dengan laba fiskal. BTD dihitung melalui selisih laba yang dilaporkan ke pemilik saham (laba buku) dengan laba yang dilaporkan untuk perpajakan (laba fiskal) yang dibagi dengan total aset (Hanlon, 2005). Laba yang dilaporkan untuk perpajakan (laba fiskal) dihitung berdasarkan pendapatan bersih perusahaan yang dibagi dengan 1 (satu) dikurangi dengan tarif pajak suatu negara (Pohan, 2009 yang mengutip Wild, dkk (2007)).

$$
\begin{aligned}
& B T D=\frac{\text { Pretax Income }- \text { Taxable Income }}{\text { Total Asset }} \\
& \text { Taxable Income }=\frac{\text { Net Income }}{1-t}
\end{aligned}
$$




\section{Tunneling Incentive}

Tunneling incentive adalah suatu perilaku dilakukan oleh pemilik saham besar dengan memindahkan aset serta keuntungan perusahaan untuk kepentingan mereka sendiri, tetapi pemilik saham kecil berbagi biaya yang mereka tanggung (Jumaidi dkk, 2018). Variabel tunnelling incentive didasarkan pada rasio ekuitas pihak asing atau perusahaan asing sebesar $20 \%$ atau lebih tinggi. Menurut PSAK No. 15, jika modal suatu entitas mencapai atau melebihi $20 \%$, maka dianggap entitas tersebut mempunyai pengaruh signifikan langsung atau tidak langsung terhadap entitas lain (Ayu dkk, 2017). Perhitungan tunneling incentive diperoleh dengan rumus berikut:

$$
T N C=\frac{\text { Jumlah Kepemilikan Saham }}{\text { Jumlah Saham Beredar }}
$$

\section{Debt Covenant}

Debt covenant adalah perjanjian yang dirancang guna menyelamatkan pemberi pinjaman (pemberi pinjaman atau kreditor) dari pelanggaran manajer atas kepentingan kreditur, seperti dividen yang berlebihan, pinjaman tambahan atau modal kerja dan properti pemilik berada di bawah tingkat yang telah ditetapkan, semua ini akan mengurangi agunan (atau meningkatkan risiko) (Junaidi dan Yuniarti, 2020). Debt covenant diproksikan dengan rasio utang, dalam penelitian ini menggunakan DER (Debt To Equity Ratio) yang diukur dengan rumus sebagai berikut (Indrasti, 2016):

$$
D E R=\frac{\text { Total Utang }}{\text { Total Ekuitas }}
$$

\section{Populasi dan Sampel}

Populasi ialah sekumpulan individu yang mempunyai karakteristik unik, dan karakteristik tersebut dijadikan ruang lingkup yang akan diteliti (Sugiyono, 2013). Penelitian ini menggunakan sampel perusahaan manufaktur yang terdaftar di Bursa Efek Indonesia (BEI) dari tahun 2015 hingga 2019. Metode purposive sampling digunakan peneliti dalam pengambilan sampel, dimana purposive sampling ialah suatu teknik penentuan sampel dengan adanya pertimbangan tertentu atau seleksi khusus (Siyoto dan Sodik, 2015). Setelah dilakukan pengolahan didapatkan sampel sebanyak 21 perusahaan dengan kriteria pengambilan sampel untuk penelitian ini adalah sebagai berikut:

1) Perusahaan multinasional dibidang manufaktur yang terdaftar di Bursa Efek Indonesia (BEI) dari 2015 hingga 2019.

2) Perusahaan multinasional dibidang manufaktur yang secara konsisten dan lengkap merilis laporan tahunan (annual report) selama 2015-2019.

3) Perusahaan multinasional dibidang manufaktur yang dikendalikan dengan persentase kepemilikan saham sebesar 20\% atau lebih oleh perusahaan asing. Hal ini sesuai dengan Pernyataan Standar Akuntansi Keuangan No. 15 yang 
mengutarakan bahwa pemilik saham pengendali ialah pihak yang mempunyai $20 \%$ atau lebih saham atau efek yang bersifat ekuitas.

4) Perusahaan multinasional dibidang manufaktur yang tidak mengalami kerugian selama 2015-2019.

\section{Teknik Pengumpulan Data}

Studi dokumentasi merupakan teknik pengumpulan data yang digunakan dalam penelitian ini. Jenis data dalam penelitian ini adalah data sekunder yang merupakan data yang didapati atau dikumpulkan peneliti dari berbagai ragam sumber yang telah ada. Data sekunder penelitian ini berbentuk laporan keuangan tahunan perusahaan manufaktur dari tahun 2015 sampai tahun 2019, yang diakses melalui laman Bursa Efek Indonesia dan laman perusahaan.

\section{Teknik Analisis}

Dalam penelitian kuantitatif, analisis data merupakan kegiatan setelah mengumpulkan data dari sumber data lain. Alat analisis yang digunakan dalam penelitian ini adalah analisis deskriptif dan analisis inferensi melalui bantuan program IBM SPSS Statistics 25 model regresi logistik dengan uji hipotesis melalui Uji Koefisien Nagelkerke's $R$ Square dan Uji Hipotesis Secara Parsial (Uji Wald). Adapun persamaan regresi logistik untuk seluruh variabel yakni:

$$
\operatorname{Ln}\left(\frac{P}{1-P}\right)=\alpha+\beta_{1} X_{1}+\beta_{2} X_{2}+\beta_{3} X_{3}+e
$$

$\mathrm{P}$ merupakan probabilitas perusahaan melakukan transfer pricing, $\alpha$ adalah konstanta, $\beta_{1-} \beta_{6}$ adalah koefisien regresi, $\mathrm{X}_{1}$ adalah pajak penghasilan $(\mathrm{PPh}), \mathrm{X}_{2}$ adalah tunneling incentive (TNC), $\mathrm{X}_{3}$ adalah debt covenant (DC) dan e adalah error.

\section{HASIL PENGUJIAN HIPOTESIS} Analisis Statistik Deskriptif

Tabel 1. Frekuensi Transfer Pricing

\begin{tabular}{rrrrrr}
\hline & & Frequency & Percent & Valid Percent & Cumulative Percent \\
\hline Valid & 0 & 5 & 4.8 & 4.8 & 4.8 \\
\cline { 2 - 6 } & 1 & 100 & 95.2 & 95.2 & 100 \\
\cline { 2 - 6 } & Total & 105 & 100 & 100 & \\
\hline
\end{tabular}

Sumber: Hasil olah data SPSS (2020)

Berdasarkan hasil tabel 1 terlihat distribusi frekuensi pada variabel transfer pricing diwakili oleh terdapatnya transaksi penjualan kepada pihak berelasi sebagai 1 dan tidak ada transaksi penjualan sebagai 0 . Di antara 105 perusahaan sampel dari 
tahun 2015 hingga 2019, terdapat 5 sampel tidak melakukan transfer pricing terhitung sekitar 4,8\%. Sampel 100 perusahaan sisanya melaksanakan transfer pricing, terbukti dari penjualan yang dilakukan kepada pihak berelasi terhitung 95,2\%. Hal ini membuktikan bahwa dibandingkan dengan perusahaan yang tidak melakukan transfer pricing, kegiatan ini lebih banyak dilakukan oleh perusahaan manufaktur yang tercatat di BEI.

Tabel 2. Hasil Uji Statistik Deskriptif

\begin{tabular}{lccccc}
\hline & N & Minimum & Maksimum & Mean & $\begin{array}{c}\text { Standar } \\
\text { Deviasi }\end{array}$ \\
\hline Pajak Penghasilan & 105 & $-1,188$ & 0,068 & $-0,016$ & 0,118 \\
\hline Tunneling Incentive & 105 & 0,205 & 0,929 & 0,546 & 0,208 \\
\hline Debt Covenant & 105 & 0,153 & 5,023 & 0,884 & 0,764 \\
\hline
\end{tabular}

Sumber: Hasil olah data SPSS (2020)

Sesuai dengan tabel 2, jumlah data (N) yang digunakan sebanyak 105 data. Variabel pajak penghasilan diperoleh nilai rata-rata sebesar -0,016 dengan standar deviasi 0,118. Nilai minimum sebesar -1,188 dan nilai maksimum sebesar 0,068. Pada variabel tunneling incentive diperoleh nilai rata-rata sebesar 0,546 dengan standar deviasi 0,208. Nilai minimum sebesar 0,205 dan nilai maksimum sebesar 0,929. Selanjutnya untuk variabel debt covenant diperoleh nilai rata-rata sebesar 0,884 dengan standar deviasi 0,764 . Nilai minimum sebesar 0,153 dan nilai maksimum sebesar 5,023.

\section{Uji Multikolinearitas}

Tabel 3. Hasil Uji Multikolinearitas

\begin{tabular}{lll}
\hline \multirow{2}{*}{ Model } & \multicolumn{2}{c}{$\begin{array}{c}\text { Collinearity } \\
\text { Statistics }\end{array}$} \\
\cline { 2 - 4 } & \multicolumn{3}{c}{ Tolerance } & VIF \\
\hline (Constant) & & \\
\hline Pajak Penghasilan & 0,964 & 1,037 \\
\hline Tunneling Incentive & 0,924 & 1,082 \\
\hline Debt Covenant & 0,954 & 1,049 \\
\hline
\end{tabular}

Sumber: Hasil olah data SPSS (2020)

Secara keseluruhan, hasil nilai Variance Inflation Factor (VIF) setiap variabel bebas tidak mempunyai nilai lebih besar dari 10 atau VIF $<10$. Sementara nilai tolerance pada setiap variabel bebas lebih besar dari 0,10 atau nilai tolerance $>0,10$. Dengan demikian, dapat disimpulkan bahwa tidak terdapat gejala multikolinearitas dalam model regresi dan dapat diuji. 
Uji Menilai Keseluruhan Model (Overall Model Fit)

Tabel 4. Hasil Overall Model Fit Test 0

Block 0 = Beginning Block

\begin{tabular}{lccc}
\hline & \multicolumn{2}{c}{ Iteration History $\mathbf{a , b , c}$} \\
\hline Iteration & & 2 Log likelihood & Coefficients Constant \\
\hline Step 0 & 1 & 49,938 & 1,810 \\
\hline & 2 & 41,141 & 2,579 \\
\hline & 3 & 40,225 & 2,928 \\
\hline 4 & 40,203 & 2,994 \\
\hline 5 & 40,203 & 2,996 \\
\hline 6 & 40,203 & 2,996 \\
\hline
\end{tabular}

Sumber: Hasil olah data SPSS (2020)

Tabel 5. Hasil Overall Model Fit Test 1

Block Number $=1$

\begin{tabular}{rrrrrrr}
\hline \multirow{2}{*}{ Iteration } & \multicolumn{5}{c}{$\begin{array}{c}\text { 2 Log } \\
\text { likelihood }\end{array}$} & \multicolumn{4}{c}{ Coefation History } \\
\cline { 4 - 7 } & & & Constant & $\begin{array}{c}\text { Pajak } \\
\text { Penghasilan }\end{array}$ & $\begin{array}{c}\text { Tunneling } \\
\text { Incentive }\end{array}$ & $\begin{array}{c}\text { Debt } \\
\text { Covenant }\end{array}$ \\
\cline { 4 - 7 } Step 1 & 1 & 47,137 & 0,993 & 0,200 & 1,313 & 0,115 \\
\hline & 2 & 34,001 & 0,449 & 0,583 & 3,585 & 0,320 \\
\hline 3 & 28,682 & $-0,969$ & 1,291 & 7,121 & 0,673 \\
\hline 4 & 26,484 & $-2,411$ & 2,174 & 10,759 & 1,112 \\
\hline 5 & 25,969 & $-3,305$ & 2,807 & 13,270 & 1,392 \\
\hline 6 & 25,929 & $-3,569$ & 2,978 & 14,171 & 1,439 \\
\hline 7 & 25,929 & $-3,592$ & 2,982 & 14,268 & 1,437 \\
\hline 8 & 25,929 & $-3,592$ & 2,982 & 14,269 & 1,437 \\
\hline 9 & 25,929 & $-3,592$ & 2,982 & 14,269 & 1,437 \\
\hline
\end{tabular}

Sumber: Hasil olah data SPSS (2020)

Dari hasil pada tabel 4 dan 5, dapat terlihat perbandingan antara nilai -2LL blok awal dengan -2LL blok akhir. Dari hasil perhitungan nilai -2LL tampak bahwa nilai -2LL di blok awal (Block Number $=0$ ) adalah senilai 40,203 dan nilai -2LL di blok akhir (Block Number $=1$ ) adalah senilai 25,929. Selisih antara blok awal dan blok akhir senilai 14,274. Hasil perhitungan nilai -2LL dapat dilihat bahwa nilai 2LL mengalami penurunan. Penurunan ini menyatakan bahwa model dapat diterima dan dihipotesiskan. Dapat disimpulkan bahwa dengan menambah variabel Pajak Penghasilan, Tunneling Incentive, dan Debt Covenant akan memperbaiki model regresi atau berarti model fit dengan data. 


\section{Uji Kelayakan Model Regresi (Goodness of Fit Test)}

Tabel 6. Hasil uji Hosmer and Lemeshow's Goodness of Fit Test

\begin{tabular}{cccc}
\hline \multicolumn{4}{c}{ Hosmer and Lemeshow Test } \\
\hline Step & Chi-square & df & Sig. \\
\hline $\mathbf{1}$ & 1,010 & 8 & 0,998 \\
\hline
\end{tabular}

Sumber: Hasil olah data SPSS (2020)

Dapat dilihat dari hasil tersebut nilai Chi-Square sebesar 1,010 dan nilai signifikansi jauh lebih tinggi dari 0,05 $(0,998>0,05)$, sehingga hasil tersebut menunjukkan bahwa model dapat memprediksi nilai diamati, atau dapat dikatakan model dapat diterima karena sesuai dengan data yang diamati.

\section{Uji Koefisien Nagelkerke's R Square}

Tabel 7. Hasil Uji Koefisien Nagelkerke's R Square

\begin{tabular}{rrrr}
\hline Step & $\mathbf{- 2 ~ L o g ~ l i k e l i h o o d}$ & Cox \& Snell R Square & Nagelkerke R Square \\
\hline $\mathbf{1}$ & $25,929^{\mathrm{a}}$ & 0,127 & 0,400 \\
\hline
\end{tabular}

Sumber: Hasil olah data SPSS (2020)

Berdasarkan tabel 7 dapat dilihat nilai Nagelkerke $R$ Square adalah 0,400. Hal ini membuktikan variabel independen penelitian ini (pajak penghasilan, tunneling incentive, dan debt covenant) dapat mengartikan variabel dependen yakni transfer pricing sebesar $40 \%$, dan $60 \%$ sisanya diartikan oleh variabel-variabel selain penelitian ini.

\section{Uji Hipotesis Secara Parsial (Uji Wald)}

Tabel 8. Hasil Uji Koefisien Regresi (Parsial)

\begin{tabular}{llccccc}
\hline & & $\boldsymbol{B}$ & $\boldsymbol{S . E}$. & Wald & $\boldsymbol{d f}$ & Sig. \\
\hline Step 1 $^{\text {a }}$ & Pajak Penghasilan & 2,982 & 13,275 & 0,050 & 1 & 0,822 \\
\cline { 2 - 7 } & $\begin{array}{l}\text { Tunneling } \\
\text { Incentive }\end{array}$ & 14,269 & 5,642 & 6,398 & 1 & 0,011 \\
\cline { 2 - 7 } & & & & & \\
\cline { 2 - 7 } Debt Covenant & 1,437 & 1,506 & 0,911 & 1 & 0,340 \\
\hline Constant & $-3,592$ & 2,225 & 2,608 & 1 & 0,106
\end{tabular}

Sumber: Hasil olah data SPSS (2020)

Untuk mengukur signifikansi koefisien masing-masing variabel independen digunakan $p$-value (nilai probabilitas) dengan derajat signifikansi 0,05. Jika hasil signifikansi di bawah 0,05 maka koefisien regresi dinyatakan signifikan. Tabel $9 \mathrm{di}$ atas, diperoleh statistik wald dengan variabel Pajak Penghasilan 0,050 dan tabel Chi-Square dengan tingkat signifikansi 0,05, sehingga didapatkan Chi-Square 
3,841. Hasil probabilitas ( $\mathrm{Sig}$ ) senilai 0,822 dan di atas derajat signifikan $(0,822>$ 0,05). Hasil perhitungan wald di bawah tabel Chi Square yakni 0,050 <3,841. Hal ini menunjukkan Ho diterima dan Ha ditolak. Oleh sebab itu, dapat disimpulkan bahwa pajak penghasilan tidak berpengaruh terhadap indikasi transfer pricing.

Selanjutnya, statistik wald dari variabel Tunneling Incentive adalah 6,398 dan tabel Chi-Square dengan derajat signifikan 0,05. Hasil probabilitas (Sig) sebesar 0,015 yang hasilnya di bawah dari derajat signifikan $(0,011<0,05)$. Hasil perhitungan wald di atas tabel Chi-Square yakni 6,398>3,841. Hal ini menunjukkan Ho ditolak dan Ha diterima. Oleh sebab itu, dapat disimpulkan bahwa tunneling incentive berpengaruh positif signifikan terhadap indikasi transfer pricing.

Untuk debt covenant memiliki statistik wald 0,911 dan tabel Chi-Square dengan derajat signifikan 0,05. Hasil probabilitas (Sig) sebesar 0,340 dan di atas derajat signifikan $(0,340>0,05)$. Hasil perhitungan wald di bawah tabel Chi-Square yakni $0,911<3,841$. Hal ini membuktikan bahwa Ho diterima dan Ha ditolak. Oleh karena itu, dapat disimpulkan bahwa debt covenant tidak berpengaruh signifikan terhadap indikasi transfer pricing.

\section{Analisis Regresi Logistik}

Persamaan regresi logistik yang dibentuk dengan cara ini adalah sebagai berikut:

$$
\operatorname{Ln}\left(\frac{\mathrm{TP}}{1-\mathrm{TP}}\right)=-3,592+2,982 \mathrm{PPh}+14,269 \mathrm{TNC}+1,437 \mathrm{DC}+\mathrm{e}
$$

\section{Pembahasan Hasil Penelitian}

\section{Pajak Penghasilan dan Transfer Pricing}

Berdasarkan hasil perhitungan dan uji regresi logistik pada hipotesis pertama yang telah dilakukan, variabel pajak penghasilan tidak berpengaruh terhadap indikasi transfer pricing. Hasil penelitian ini tidak menerima hipotesis pertama $\left(\mathrm{H}_{1}\right)$. Beban pajak yang tinggi tidak membuat perusahaan mengambil keputusan melakukan transfer pricing, begitupun sebaliknya perusahaan yang memiliki beban pajak yang rendah belum tentu disebabkan oleh transfer pricing. Tidak ditemukannya pengaruh pajak penghasilan terhadap indikasi transfer pricing, mungkin dikarenakan perusahaan menggunakan cara lain untuk meminimalkan beban pajak perusahaan, misalnya melalui manajemen pajak. Hasil penelitian ini sejalan dengan penelitian yang dilakukan oleh Andayani dan Sulistyawati (2020) serta Tjandrakirana dan Diani (2020) menunjukkan pajak penghasilan tidak akan mempengaruhi keputusan perusahaan dalam melakukan transfer pricing. Perusahaan yang membayar pajak lebih rendah tidak akan membuat perusahaan mengambil keputusan untuk melakukan transfer pricing. Akan tetapi penelitian ini tidak sejalan dengan penelitian yang dilakukan oleh Ayu dkk (2017), Jumaidi dkk 
(2018), serta Wijaya dan Amalia (2020), dimana pajak penghasilan berpengaruh terhadap keputusan perusahaan melakukan transfer pricing.

\section{Tunneling Incentive dan Transfer Pricing}

Berdasarkan hasil perhitungan dan uji regresi logistik pada hipotesis kedua yang telah dilakukan, variabel tunneling incentive mempunyai pengaruh yang positif signifikan terhadap indikasi transfer pricing. Hasil tersebut sejalan dengan hipotesis yang diajukan. Hal ini menunjukkan bahwa perusahaan yang kepemilikannya terfokus pada satu pihak atau satu kepentingan cenderung akan melakukan tunneling di dalamnya melalui transaksi transfer pricing. Tujuannya untuk menaikkan keuntungan pemilik saham mayoritas sehingga menimbulkan kerugian bagi pemilik saham minoritas. Penelitian ini sejalan dengan penelitian yang dilakukan oleh Andayani dan Sulistyawati (2020) serta Ayu dkk (2017) menunjukkan bahwa tunneling incentive memberikan pengaruh positif signifikan terhadap keputusan transfer pricing, dijelaskan bahwa kepemilikan perusahaan hanya dikendalikan oleh beberapa pihak, dan pihak yang mengendalikan perusahaan tersebut seringkali melakukan tindakan yang hanya menguntungkan dirinya sendiri. Hal tersebut dicapai melalui tunneling incentive untuk meningkatkan keuntungan individu pemilik saham pengendali (pemilik saham mayoritas) melalui transaksi transfer pricing, namun pemilik saham minoritas juga ikut menanggung beban dari transaksi ini. Akan tetapi penelitian ini tidak sejalan dengan penelitian yang dilakukan oleh Nabila dkk (2020) serta Wijaya dan Amalia (2020) yang mengatakan bahwa tunneling incentive tidak berpengaruh terhadap transfer pricing.

\section{Debt Covenant dan Transfer Pricing}

Berdasarkan hasil perhitungan dan uji regresi logistik pada hipotesis ketiga yang telah dilakukan, variabel debt covenant tidak berpengaruh terhadap indikasi transfer pricing, sehingga hasil penelitian ini menolak hipotesis ketiga $\left(\mathrm{H}_{3}\right)$. Debt covenant (perjanjian utang) adalah perjanjian yang dirancang untuk menyelamatkan pemberi pinjaman dari tindakan manajer terhadap kepentingan kreditor. Perjanjian ini membatasi segala aktivitas perusahaan seperti membatasi pembagian dividen, membatasi untuk berinvestasi, dan mengurangi kemungkinan subsitusi aset. Dengan adanya pembatasan tersebut akan menyebabkan perusahaan melanggar peraturan karena tidak bisa melakukan sesuatu secara bebas. Pelanggaran tersebut bisa dihindari, karena perusahaan akan cenderung melaksanakan transfer pricing. Hasil penelitian ini sesuai dengan penelitian Indrasti (2016) yang menyatakan bahwa debt covenant tidak berpengaruh terhadap keputusan perusahaan melakukan transfer pricing. Akan tetapi tidak sejalan dengan penelitian Jumaidi dkk (2018) serta Tjandrakirana dan Diani (2020) yang 
menyatakan bahwa debt covenant mempengaruhi keputusan perusahaan untuk menerapkan transfer pricing.

\section{KESIMPULAN}

Berdasarkan hasil perhitungan dan pengujian transfer pricing pada 21 perusahaan manufaktur yang terdaftar di Bursa Efek Indonesia (BEI) dari tahun 2015 hingga 2019, dapat ditarik kesimpulan sebagai berikut: (1) Pajak penghasilan tidak berpengaruh terhadap indikasi transfer pricing. Hasil analisis logistik uji wald membuktikan dengan taraf signifikansi sebesar 0,822 lebih besar dari 0,05 dan hasil koefisien pajak penghasilan positif sebesar 2,982, yang berarti tingginya beban pajak yang harus dibayar perusahaan tidak berpengaruh terhadap indikasi transfer pricing; (2) Tunneling incentive berpengaruh terhadap indikasi transfer pricing. Hasil analisis logistik uji wald membuktikan dengan taraf signifikansi sebesar 0,011 lebih kecil dari 0,05 dan hasil koefisien tunneling incentive positif sebesar 14,269, yang berarti semakin besar saham yang dimiliki oleh pemilik saham maka kecenderungan perusahaan melaksanakan transfer pricing akan semakin besar; dan (3) Debt covenant tidak berpengaruh terhadap indikasi transfer pricing. Hasil analisis logistik uji wald membuktikan dengan taraf signifikansi sebesar 0,340 lebih besar dari 0,05 dan hasil koefisien debt covenant bernilai positif sebesar 1,437, artinya debt covenant tidak berpengaruh terhadap indikasi transfer pricing.

Adapun keterbatasan yang terdapat dalam penelitian ini diantaranya: (1) Dari 188 perusahaan manufaktur yang terdaftar di Bursa Efek Indonesia (BEI), hanya 21 perusahaan yang dapat dijadikan sampel dikarenakan perusahaan tersebut tidak memenuhi kriteria pengambilan sampel yang ditetapkan; (2) Teori yang berkaitan dengan debt covenant masih sedikit, sehingga sulit bagi penulis untuk mengidentifikasi teori-teori yang tepat dijadikan dasar untuk mendukung hasil penelitian ini; dan (3) Nilai Nagelkerke $R$ Square dalam penelitian ini relatif rendah yakni senilai 0,400 . Hal ini menunjukkan bahwa pajak penghasilan, tunneling incentive, dan debt covenant hanya mampu mempengaruhi indikasi transfer pricing sebesar $40 \%$, dan $60 \%$ sisanya diartikan oleh variabel-variabel selain penelitian ini.

Berdasarkan keterbatasan yang ada dalam penelitian ini, untuk kedepannya diinginkan dapat menampilkan hasil penelitian yang lebih bermutu melalui beberapa saran berikut yaitu (1) Direkomendasikan untuk menggunakan variabel lain seperti mekanisme bonus dan good corporate governance; (2) Obyek penelitian disarankan untuk menggunakan masing-masing sub sektor manufaktur yang dapat memperoleh hasil lebih detail serta berbeda, dimana masing-masing sektor industri memiliki kriteria yang tidak sama; (3) Penelitian selanjutnya hendaknya memakai jangka waktu yang lebih panjang, agar memberikan hasil yang lebih baik; dan (4) Menggunakan pengukuran terbaru seperti proksi nilai Related Party Transaction (RPT) untuk menghitung transfer pricing. 


\section{DAFTAR PUSTAKA}

Amanah, K., \& Suyono, N. A. (2020). Pengaruh Profitabilitas, Mekanisme Bonus, Tunneling Incentive, Dan Debt Covenant Terhadap Transfer Pricing Dengan Tax Minimization Sebagai Variabel Moderasi (Studi Empiris pada Perusahaan Manufaktur yang memiliki Hubungan Istimewa yang terdaftar di BE. 2(1), 1-13.

Andayani, A. S., \& Sulistyawati, A. I. (2020). Pengaruh Pajak, Tunneling Incentive dan Good Corporate Governance (GCG) dan Mekanisme Bonus Terhadap Indikasi Transfer Pricing pada Perusahaan Manufaktur. Majalah Ilmiah Solusi, 18(1), 33-50.

Ayu, G., Surya, R., \& Sujana, I. K. (2017). Pengaruh Pajak, Mekanisme Bonus, Dan Tunneling Incentive Pada Indikasi Melakukan Transfer Pricing. E-Jurnal Akuntansi, 19, 1000-1029.

Hanlon, M. (2005). The persistence and pricing of earnings, accruals, and cash flows when firms have large book-tax differences. Accounting Review, 80(1), 137-166. https://doi.org/10.2308/accr.2005.80.1.137

Indrasti, A. W. (2016). Pengaruh Pajak, Kepemilikan Asing, Bonus Plan dan Debt Covenant Terhadap Keputusan Perusahaan Untuk Melakukan Transfer Pricing (Studi Empiris Pada Perusahaan Manufaktur yang Terdaftar di Bursa Efek Indonesia Tahun 2012-2015). PROFITA, 9(3), 348-371.

Jensen, C., \& Meckling, H. (1976). Theory Of The Firm: Managerial Behavior, Agency Costs And Ownership Structure I. In addition to tying together elements of the theory of e. 3, 305-360.

Johnson, S., Porta, R. La, Lopez-De-Silanes, F., \& Shleifer, A. (2000). Tunneling. 90, 22-26.

Jumaidi, L. T., Bambang, \& Hudaya, R. (2017). Analisis Pajak, Tunneling, Gross Margin, dan KAP Spesialis terhadap Keputusan Untuk Melakukan Transfer Pricing. Jurnal Aplikasi Akuntansi, 1(2), 1-21.

Junaidi, A., \& Yuniarti, N. (2020). Pengaruh Pajak, Tunneling Incentive, Debt Covenant Dan Profitabilitas Terhadap Keputusan Melakukan Transfer Pricing. Jurnal Ilmiah Akuntansi, Manajemen Dan Ekonomi Islam (JAM-EKIS), 3(1), 31-44. https://doi.org/10.36085/jam-ekis.v3i1.530

Lingga, I. (2015). Aspek Perpajakan dalam Transfer Pricing dan Problematika Praktik Penghindaran Pajak (Tax Avoidance). Jurnal Zenit, 1(3), 1-14.

Morris, R. D. (1987). Signalling, Agency Theory and Accounting Policy Choice. Accounting and Business Research, 18(69), 47-56. https://doi.org/10.1080/00014788.1987.9729347

Mulyani, H. S., Prihartini, E., \& Sudirno, D. (2020). Analisis Keputusan Transfer Pricing Berdasarkan Pajak, Tunneling dan Exchange Rate. Jurnal Akuntansi Dan Pajak, 20(2), 171-181. https://doi.org/10.29040/jap.v20i2.756 
Nabila, R., Widiastuti, N. P. E., \& Aswar, K. (2020). Dampak Pajak, Tunneling Incentive, Leverage, dan Exchange Rate Terhadap Perlakuan Transfer Pricing. KORELASI I (Konferensi Riset Nasional Ekonomi, Manajemen, Dan Akuntansi), 293-312.

Osho, A., \& Ilori, F. O. (2020). Influence of Transaction Transfer Pricing Policies on Corporate Organizations Tax in Nigeria. Research Journal of Finance and Accounting, 4(3), 34-43. https://doi.org/10.7176/rjfa/11-6-07

Pohan, T. H. (2009). Analisis Pengaruh Kepemilikan Institusi, Rasio Tobin Q, Akrual Pilihan, Tarif Efektif Pajak, dan Biaya Pajak Ditunda Terhadap Penghindaran Pajak Pada Perusahaan Publik. Jurnal Informasi, Perpajakan, Akuntansi Dan Keuangan Publik, 4(2), 113-135.

Putri, W. A. (2018). Prinsip Kewajaran dan Dokumen sebagai Penangkal Kecurangan. 6(1), 1-10.

Sari, A. N., \& Puryandani, S. (2019). Pengaruh Pajak, Tunneling Incentive, Good Corporate Governance dan Mekanisme Bonus terhadap Transfer Pricing (Studi Kasus pada Perusahaan Pertambangan yang Tercatat di BEI Periode 2014-2017). Sustainable Competitive Advantage-9 (Sca-9) FEB UNSOED, 9(148), hal. 148-156.

Siyoto, S., \& Sodik, M. A. (2015). Dasar Metodologi Penelitian. Yogyakarta: Literasi Media Publishing

Sugiyono. (2013). Metode Penelitian Kuantitatif Kualitatif dan R\&D. Alfabeta: Bandung

Suryarini, T., Cahyaningrum, A. M., \& Hidayah, R. (2020). The Effect of Tunneling Incentive to Transfer Pricing Decision with Tax Minimization As a Moderating Variable. KnE Social Sciences, 2020(2010), 1-13. https://doi.org/10.18502/kss.v4i6.6584

Tarigan, L. B. (2017). Pengaruh Pajak, Mekanisme Bonus, Ukuran Perusahaan, Kepemilikan Asing, Dan Tunneling Incentive Terhadap Transfer Pricing. JOMFekon, 4(1), 1960-1970.

Tjandrakirana, R., \& Diani, E. (2020). Tax, Debt Covenant and Exchange Rate (Analisis Atas Fenomena Transfer Pricing). Balance: Jurnal Akuntansi Dan Bisnis, 5(1), 26. https://doi.org/10.32502/jab.v5i1.2456

Wijaya, I., \& Amalia, A. (2020). Pengaruh Pajak, Tunneling Incentive, Dan Good Corporate Governance Terhadap Transfer Pricing. Jurnal Profita, 13(1), 30. https://doi.org/10.22441/profita.2020.v13i1.003 